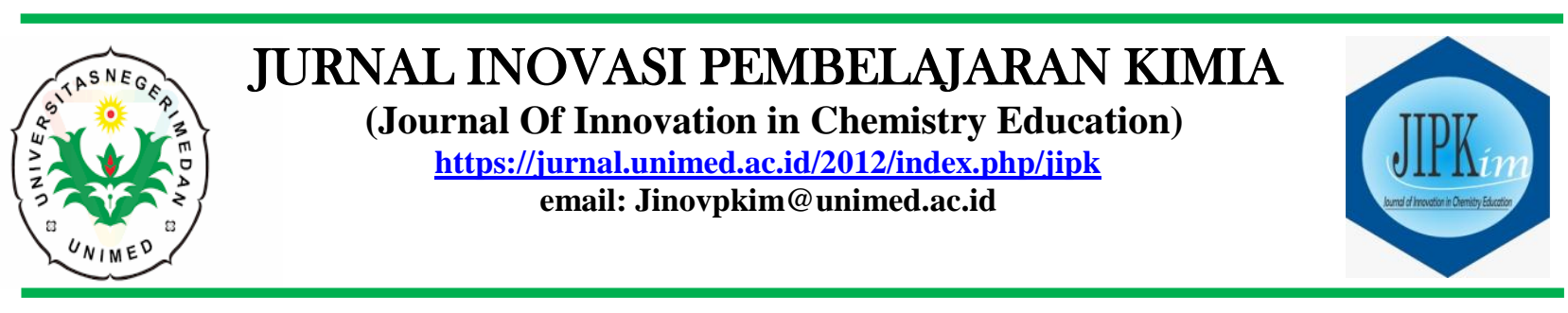

$\begin{array}{ll}\text { Masuk } & : \text { 19 September } 2021 \\ \text { Revisi } & : \text { 25 September } 2021 \\ \text { Diterima } & : \text { 24 Oktober } 2021 \\ \text { Diterbitkan } & : \text { 31 Oktober } 2021 \\ \text { Halaman } & : 148-163\end{array}$

\title{
Pengembangan E-Magazine Reaksi Reduksi dan Oksidasi Sebagai Media Pembelajaran Kimia Kelas X SMA/MA
}

\author{
Maipha Deapati Arief ${ }^{*}$, Army Auliah ${ }^{1}, \operatorname{Hardin}^{1}$ \\ ${ }^{1}$ Program Studi Pendidikan Kimia, Universitas Negeri Makassar, Makassar \\ *Alamat Korespondensi: Maiphadeapati08arief@gmail.com
}

\begin{abstract}
The problem of the Covid-19 pandemic world that social distancing is applied for all social and educational activities and requires distance learning. Therefore, to support the success of distance learning, teachers must be able to prepare learning media that support subject matter in the distance learning process. The media that can be developed is e-magazine, which is a magazine with an attractive appearance and can be accessed electronically. The purpose of this development research is to determine the profile and quality of e-magazine as a learning medium by using the ADDIE model development research method which consists of Analysis, Design, Development, Application, using research instruments namely observation sheets, questionnaires, and evaluation questions and feasibility tests are reviewed. from the results of the validity of media experts, material experts, effective and practical limited trials with responses from teachers and students who will use this e-magazine with quantitative data types using a Likert scale and Post Test. The object of the research is the e-magazine of the reduction and oxidation reaction which was developed and the result of the development is that the e-magazine of the material for the reduction and oxidation reaction has met the valid, practical, and effective criteria.
\end{abstract}

Keywords: E-magazine, Media, Development, Reduction and Oxidation Reactions.

\section{PENDAHULUAN}

Media pembelajaran merupakan salah satu bagian terpenting dalam kegiatan belajar dan mengajar atau pada proses penyampaian pesan atau informasi guru ke peserta didik. Dengan demikian, demi tercapainya proses pembelajaran yang efektif dan efisien serta menarik, pemilihan media pembelajaran yang dirancang dengan tepat sesuai dengan kebutuhan peserta didik dapat membantu tercapainya hal tersebut. Selain itu, Media pembelajaran juga berperan sebagai sumber belajar bagi peserta didik. Salah satu sumber belajar untuk membantu guru dan peserta didik yang paling umum digunakan yaitu media bahan cetak yang mempunyai kelebihan akan kemampuannya menyajikan informasi dalam jumlah banyak, namun sumber belajar berbahan cetak masih banyak memiliki kekurangan baik dalam segi kedalaman materi maupun bentuk tampilannya (Indriana, 2011). Hal ini dapat menimbulkan efek jenuh peserta didik dalam aktivitas membaca materi pelajaran, khususnya materi yang banyak memiliki konsep abstrak seperti mata pelajaran kimia. 
Oleh karena itu media pembelajaran hendaknya dirancang sesuai dengan keadaan dan kebutuhan peserta didik.

Permasalahan dunia saat ini termasuk negara Indonesia yang sedang mengalami pandemi Covid-19, sehingga diterapkan social distancing untuk seluruh kegiatan sosial maupun pendidikan dan mengharuskan adanya pembelajaran jarak jauh (belajar dari rumah). Oleh karena itu, untuk menunjang keberhasilan belajar jarak jauh guru harus mampu menyiapkan media pembelajaran yang mendukung materi mata pelajaran dalam proses pembelajaran jarak jauh (Febrilia et al., 2020)

Materi pelajaran kimia yang mempelajari struktur, susunan, sifat dan perubahan pada materi serta energi yang menyertainya cukup sulit untuk dipelajari. Hal tersebut dikarenakan ada beberapa cakupan materi ajar berupa konsep-konsep yang bersifat abstrak dan kompleks, sehingga peserta didik sulit untuk memahami representasi pada hal-hal yang bersifat abstrak dan tidak dapat diamati secara langsung oleh peserta didik (Ristiyani et al., 2016)

Peserta didik tidak dapat memahami konsep mikroskopis secara detail dikarenakan penggunaan media pembelajaran atau bahan ajar yang tersedia seperti buku paket yang dimiliki cenderung hanya berisi teori-teori kimia yang terlalu padat materinya dan juga kurangnya penjelasan dengan penambahan gambar sehingga peserta didik lebih sulit untuk mengerti apa yang dipelajari (Setiaji, S.II., dan P. Yatiman., 2013). Oleh karena itu pembelajaran kimia harus dirancang sedemikian rupa agar menjadi lebih efektif dan inovatif dengan pemilihan media pembelajaran yang tepat.

Merujuk pada permasalahan tersebut salah satu media yang dapat dikembangkan yaitu e-magazine yang merupakan sebuah majalah dengan tampilan menarik dan dapat diakses secara elektronik. Artinya dapat diakses kapan saja dan di mana saja, selain itu pengembangan bahan ajar kedalam sebuah majalah akan membantu peserta didik dalam memahami pembelajaran karena pengemasan bahan ajar ke dalam berbagai konten yang menarik dengan bahasa yang ringan dan mudah dipahami sesuai karakteristik majalah serta visualisai pelajaran menjadi lebih efektif dan diharapkan dapat meningkatkan motivasi dan minat belajar peserta didik khususnya pada mata pelajaran kimia.

Selain itu dengan adanya e-magazine ini bisa membantu peserta didik untuk dapat berpikir lebih optimum sehingga lebih mudah dalam memahami materi kimia khususnya reaksi reduksi dan oksidasi. Hal tersebut dikarenakan dalam e-magazine ini terdapat konten ringan dengan disertai pembuatan emind map untuk peserta didik yang nantinya dapat membantu peserta didik untuk lebih mudah dalam upaya mencapai tujuan pembelajaran yang diharapkan. Sejalan dengan hal ini, penelitian yang telah dilakukan oleh (pakpahan et al., 2016) tentang pengembangan majalah kimia pada materi hukum-hukum dasar kimia kelas $\mathrm{X}$ menunjukkan hasil respon peserta didik maupun guru berturut-turut sebesar $86,71 \%$ dan $83,33 \%$. Selain itu, penelitian yang telah dilakukan oleh (Puri et al., 2019) tentang pengembangan e-magazine yang dikembangkan memberikan respon yang sangat baik terhadap peserta didik sebesar 91,1\% (sangat baik) dan memiliki nilai validitas sangat baik. Berdasarkan beberapa hasil penelitian terdahulu ini dapat dikatakan pengembangan bahan ajar ke dalam sebuah majalah layak dikembangkan untuk membantu proses pembelajaran. Sesuai permasalahan tersebut maka penulis berkeinginan untuk mengembangkan sebuah media pembelajaran e-magazine menggunakan model pengembangan ADDIE yang terdiri dari Analisis, Desain, Pengembangan, Penerapan, Evaluasi yang disesuaikan dengan karakteristik peserta didik salah satunya pada minat, gaya belajar, dan motivasi belajar peserta didik dengan tahapan Analisis menggunakan instrumen penelitian yaitu lembar observasi, angket, dan soal evaluasi serta uji kelayakan ditinjau dari hasil validitas ahli media, ahli materi, uji coba terbatas efektif dan praktis dengan respon baik dari guru dan peserta didik yang akan menggunakan e-magazine ini. Berdasarkan 
latar belakang tersebut, rumusan masalah yang terjadi yaitu Bagaimana profil emagazine reaksi reduksi dan oksidasi yang telah dikembangkan bagi peserta didik kelas $\mathrm{X}$ SMA/MA? Bagaimana kualitas (valid, efektif, dan praktis) e-magazine reaksi reduksi dan oksidasi yang dikembangkan untuk membantu peserta didik dalam proses belajar materi reaksi reduksi dan oksidasi kelas $\mathrm{X}$ SMA/MA?

Tujuan yang ingin dicapai dalam penelitian ini adalah Untuk mengetahui profil e-magazine reaksi reduksi dan oksidasi sebagai media pembelajaran kimia bagi peserta didik kelas X SMA/MA. Untuk mengetahui kualitas e-magazine reaksi reduksi dan oksidasi yang telah dikembangkan untuk membantu peserta didik dalam proses belajar materi reaksi reduksi dan oksidasi kelas X SMA/MA.

\section{KAJIAN LITERATUR}

Majalah elektronik (electronic magazine) disingkat e-magazine atau e-zine juga disebut online magazine adalah majalah dalam bentuk elektronik karena berbasis listrik. Menurut (Oemar, Hamalik., 2009):

"Majalah adalah alat komunikasi yang bersifat umum dan terbit secara teratur, yang berfungsi sebagai penyebar informasi dan sarana perjuangan untuk mencapai tujuan tertentu”.

Majalah atau e-magazine kimia dapat digunakan sebagai media pembelajaran (sumber belajar) ataupun pendamping buku teks pelajaran kimia untuk peserta didik, terkhususnya pada materi yang mempunyai konsep yang cukup banyak terutama pada materi sejarah perkembangan redoks berdasarkan bilang oksidasi serta materi tata nama senyawa redoks sehingga dibutuhkan ringkasan penggambaran materi yang menarik dan memotivasi peserta didik. E-magazine kimia memuat informasi yang ditampilkan secara sederhana namun mendalam dengan meringkas materi pelajaran yang paling benar dan efisien yang mengandung prinsip: memilih kata kunci dan mengatur kembali kata kunci itu menjadi suatu struktur yang paling mudah dipahami dan dimengerti oleh peserta didik. E-magazine dapat digunakan sebagai media pembelajaran karena telah memenuhi manfaat praktis media pembelajaran di dalam proses belajar mengajar menurut yaitu (Cecep., 2020):

a. E-magazine sebagai media pembelajaran dapat memperjelas penyajian pesan dan informasi sehingga dapat memperlancar dan meningkatkan proses dan hasil belajar.

b. E-magazine sebagai media pembelajaran dapat meningkatkan dan mengarahkan perhatian anak sehingga dapat menimbulkan motivasi belajar, interaksi yang lebih langsung antara peserta didik dengan lingkungannya, serta kemungkinan peserta didik untuk belajar sendiri-sendiri sesuai dengan kemampuan dan minatnya.

c. E-magazine sebagai media pembelajaran dapat mengatasi keterbatasan indra, ruang dan waktu.

d. E-magazine sebagai media pembelajaran dapat memberikan kesamaan pengalaman pada peserta didik tentang peristiwa di lingkungan mereka, serta memungkinkan terjadinya interaksi langsung dengan guru, masyarakat dan lingkungan.

Penelitian pengembangan yang biasa dikenal dengan Research and Development $(R \& D)$ menurut Borg \& Gall (1983) disebutkan bahwa pada umumnya penelitina R \& D bersifat longitudinal (beberapa tahap) untuk penelitian analisis kebutuhan sehingga mampu dihasilkan produk yang bersifat hipotetik sering digunakan metode penelitian dasar selanjutnya untuk menguji produk yang masih bersifat hipotetik tersebut dugunakan eksperimen atau acion research setelah produk teruji, maka dapat diaplikasikan.

"Model ADDIE adalah kerangka kerja sederhana yang berguna untuk merancang pembelajaran dimana prosesnya dapat diterapkan dalam berbagai pengaturan karena strukturnya yang umum" sehingga dapat digunakan untuk pengembangan media pembelajaran secara tatap muka maupun secara online dan sesuai dengan kondisi kebutuhan peserta didik saat ini yang sedang melaksanakan pembelajaran jarak jauh (social distancing) serta kesesuaian model pengembangan ADDIE untuk pengembangan 
media e-magazine materi reaksi reduksi dan oksidasi yang diharapkan mampu menjadi sumber belajar peserta didik dalam pelaksanaan pembelajaran jarak jauh (social distancing).

Materi reaksi reduksi dan oksidasi akan lebih mudah untuk dipahami apabila dibantu dengan media bahan ajar seperti e-magazine yang menampilkan gambar/konten dan ringkasan materi yang sesuai karena pada materi redoks mempunyai konsep yang cukup banyak terkhususnya pada materi sejarah perkembangan redoks berdasarkan bilang oksidasi serta materi tata nama senyawa redoks sehingga dibutuhkan ringkasan penggambaran materi yang menarik dan memotivasi peserta didik.

\section{METODE}

Penelitian ini merupakan penelitian pengembangan atau Research and Development (R\&D) yang dilakukan dalam rangka menghasilkan produk e-magazine. Desain penelitian yang digunakan pada penelitian ini berdasar pada model pengembangan ADDIE yang terdiri dari lima tahap yaitu: Analysis (analisis), Design (perencanaan), Development (pengembangan), Implementation (pelaksanaan) dan Evaluation (evaluasi). Peneliti memodifikasi model pengembangan sesuai dengan kebutuhan yaitu dengan melakukan dua kali tahap implementation (pelaksanaan) dan evaluation (evaluasi), dan menggunakan angket respon dan post test yang telah di validasi oleh ahli materi dan ahli media.

Subjek penelitian ini adalah guru mata pelajaran kimia dan peserta didik untuk uji kepraktisan dengan menggunakan angket respon dan efektivitas dari produk yang dihasilkan di SMA Negeri 9 Jeneponto kelas X MIA pada tahun ajaran 2020/2021. Objek penelitian ini adalah e-magazine reaksi reduksi oksidasi yang dikembangkan menggunakan model pengembangan ADDIE.

Pengumpulan data dalam penelitian ini dilakukan dengan observasi yaitu melakukan pengamatan secara langsung dalam proses e-learning sekolah dan wawancara menggunakan lembar observasi dengan guru mata pelajaran. Angket (kuesioner) yang diberikan dikonsultasikan terlebih dahulu kepada dosen pembimbing sebelum diberikan kepada ahli media dan ahli materi sebagai uji validitas serta diberikan kepada guru dan peserta didik sebagai uji efektivitas dan uji praktis yang bertujuan untuk mengumpulkan data berkaitan dengan indikator kualitas produk e-magazine baik secara tampilan media, isi bahan pembelajaran maupun respon pengguna produk e-magazine. Dokumentasi merupakan catatan peristiwa yang sudah berlalu. Dokumentasi pada penelitian ini berupa foto atau gambar dan tulisan peserta didik SMA Negeri 9 Jeneponto pada saat proses pembelajaran menggunakan media $e$ magazine berbasis internet dan pada saat pengisian angket penilaian media pembelajaran.

Analisis data yang digunakan pada penelitian ini yaitu analisis data kuantitatif. Dalam analisis data kuantitatif menggunakan data statistik yang dapat berupa statistik deskriptif. Statistik deskriptif digunakan selama melakukan validasi yaitu berupa masukan, saran maupun kritikan terhadap $e$ magazine yang dihasilkan dari ahli media dan ahli materi dan selanjutnya dilakukan terhadap hasil instrumen berupa angket penilaian yang telah diisi oleh ahli media, ahli materi, guru mata pelajaran maupun peserta didik yang menggunakan media ini. Angket penilaian diolah dengan menggunakan skala Likert sebagai skala pengukuran pada Tabel 1:

Tabel 1. Aturan Pemberian Skor Angket Penilaian

\begin{tabular}{l|l}
\hline Kategori & Skor \\
\hline SB (sangat baik) & 4 \\
\hline B (baik) & 3 \\
\hline C (cukup) & 2 \\
\hline K (kurang) & 1 \\
\hline
\end{tabular}

Penentuan koefisien validasi hasil penilaian dari masing-masing ahli dimasukkan dalam tabulasi silang 2 x 2 yang terdiri dari kolom A, B, C, dan D. kolom A adalah sel yang menunjukkan penilai tidak relevan, kolom $\mathrm{B}$ dan $\mathrm{C}$ menunjukkan nilai 
perbedaan pandangan antara penilai (penilai pertama setuju dan penilai kedua tidak setuju atau sebaliknya). Kolom D adalah sel yang menunjukkan kedua penilai menyatakan relevan. Rekapitulasi validasi instrumen penelitian dapat dilihat pada tabel 2 (Hairida dan Astuti, 2013):

Tabel 2. Rekapitulasi Validitas Instrumen Penelitian

\begin{tabular}{cccc}
\hline \multicolumn{2}{c}{ Penilai I } & \multicolumn{2}{c}{ Penilai II } \\
\hline Tidak & Relevan & Tidak & Relevan \\
Relevan & (Skor 3- & Relevan & (Skor 3- \\
(Skor 1-2) & 4) & (Skor 1- & $4)$ \\
& & 2) & \\
\hline
\end{tabular}

Setelah instrumen penilaian divalidasi oleh ahli dan direkapitulasi, selanjutnya digunakan tabulasi silang $2 \times 2$ dapat dlihat pada tabel 3 (Hairida dan Astuti, 2013) :

Tabel 3. Tabulasi Silang

\begin{tabular}{llll} 
Tabulasi Penilaian Ahli & \multicolumn{2}{c}{ Penilai II } \\
\hline & \multicolumn{2}{c}{$\begin{array}{l}\text { Tidak Relevar } \\
\text { (skor 1-2) }\end{array}$} & $\begin{array}{l}\text { Relevan } \\
\text { (skor 3-4) }\end{array}$ \\
\hline \multirow{3}{*}{ Penilai I } & $\begin{array}{l}\text { Tidak Relevar } \\
\text { (skor 1-2) }\end{array}$ & (A) & (C) \\
\cline { 2 - 4 } & $\begin{array}{l}\text { Relevan } \\
\text { (skor 3 -4) }\end{array}$ & (B) & (D) \\
\hline
\end{tabular}

Kriteria perhitungan akan dianalisis menggunakan rumus Gregory seperti persamaan 1 (Hairida dan Astuti, 2013).

$$
\text { Validitas }=D /(A+B+C+D \text {. }
$$

Keterangan :

$\mathrm{A}=$ Sel yang menunjukkan kedua penilai menyatakan tidak relevan

$\mathrm{B}=$ Sel yang menunjukkan penilai I relevan dan penilai II tidak relevan

$\mathrm{C}=$ Sel yang menunjukkan penilai I tidak relevan dan penilai II relevan

$\mathrm{D}=$ Sel yang menunjukkan kedua penilai menyatakan relevan

Hasil validitas kemudian dicocokkan dengan kriteria kevalidan instrumen penelitian menurut (Amir \& Risnawati, 2016) pada tabel 4 :

Tabel 4. Kriteria Kevalidan Instrumen Penilaian

\begin{tabular}{ll}
\hline Nilai & Kriteria \\
\hline $0,80-1,00$ & Sangat tinggi \\
\hline $0,60-0.79$ & Tinggi \\
\hline
\end{tabular}

\begin{tabular}{ll}
\hline $0,40-0,59$ & Sedang \\
\hline $0,20-0,39$ & Rendah \\
\hline $0,00-0,19$ & Sangat Rendah \\
\hline
\end{tabular}

Analisis kepraktisan instrumen diketahui berdasarkan analisis angket respon guru dan peserta didik dengan kriteria dikatakan praktis jika diperoleh respon dengan minimal praktis nilai >60 (Nisrina Nurul Faroh, 2018). Sebelum menganalisis hasil respon, mula-mula dihitung jumlah responden melalui pilihan jawaban pada setiap butir pertanyaan. Kemudian, dicari nilai skor angket per item dengan mengalikan jumlah responden dan skor pilihan jawaban sesuai kriteria pernyataan. Skor setiap pilihan jawaban berdasarkan skala Likert pada tabel 1 Rumus yang digunakan yaitu (Prasetyo, 2012):

Skor total $=\Sigma R \times$ Skor pilihan jawaban

Keterangan :

$\Sigma \mathrm{R}:$ Jumlah responden yang memilih jawaban

Terdapat empat pilihan jawaban berdasarkan skala Likert, maka rumus untuk menghitung nilai respon guru dan peserta didik yaitu $>61 \%$ berdasarkan kriteria kepraktisan menurut (Riduwan, 2007) peserta didik dapat dilihat pada tabel 5 (Prasetyo, 2012):

Tabel 5. Rumus perhitungan respon guru dan peserta didik

\begin{tabular}{ll} 
Pernyataan & Perhitungan \\
\hline Sangat Baik $(\mathrm{SB})$ & $=\Sigma \mathrm{R} \times 4$ \\
\hline Baik $(\mathrm{B})$ & $=\Sigma \mathrm{R} \times 3$ \\
\hline Cukup $(\mathrm{C})$ & $=\Sigma \mathrm{R} \times 2$ \\
\hline Kurang $(\mathrm{K})$ & $=\Sigma \mathrm{R} \times 1$
\end{tabular}

Nilai respon guru dan peserta didik tiap jawaban akan dijumlahkan untuk tiap butir pertanyaan dan dicari persentase dengan rumus sebagai berikut (Prasetyo, 2012):

$\Sigma$ nilai $=$ Nilai $S B+$ Nilai $B+$ Nilai $C+$ Nilai $K$

Nilai Maksimal $=\Sigma$ responden $x$ Skor pilihan tertinggi $=\sum$ responden $\times 4$

Persentase $=\frac{\Sigma \text { Nilai }}{\text { Nilai } \text { maksimal }} \times 100 \%$ 
Kemudian menghitung banyaknya kriteria dari seluruh butir pernyataan selanjutnya hasil persentase dapat dilihat pada tabel 5 berdasarkan kriteria kepraktisan, media emagazine dapat dikatakan praktis apabila nilai respon guru dan peserta didik yaitu $>61 \%$ berdasarkan kriteria kepraktisan menurut (Riduwan, 2007) dapat dilihat pada tabel 6.

Tabel 6. Skala Angket Kepraktisan Media

\begin{tabular}{ll}
\hline Skor persentase & Kriteria \\
\hline $81 \%-100 \%$ & Sangat praktis \\
$61 \%-80 \%$ & Praktis \\
$41 \%-60 \%$ & Cukup praktis \\
$21 \%-40 \%$ & Tidak praktis \\
$5 \%-20 \%$ & Sangat tidak praktis \\
\hline
\end{tabular}
Sumber : (Riduwan, 2007).

Analisis keefektifan untuk tes evaluasi peserta didik menggunakan lembar penilaian kognitif. Hasil penilaian kognitif dinilai berdasarkan pedoman penskoran. Nilai maksimal untuk penilaian kognitif yaitu 100 dan untuk kriteria ketuntasan minimal (KKM) yang ditentukan oleh guru yaitu 75 . Peserta didik dikatakan tuntas jika mendapatkan nilai hasil tes evaluasi lebih besar atau sama dengan KKM. E-magazine yang dikembangkan dikatakan efektif apabila setelah peserta didik mengikuti pembelajaran yang menggunakan $e$-magazine mendapatkan nilai ketuntasan memenuhi kriteria minimal baik berdasarkan interval kriteria ketuntasan hasil tes belajar oleh (S. eko Putro Widoyoko, 2009). Perhitungan nilai hasil tes evaluasi peserta didik dilakukan dengan mengoreksi lembar jawaban peserta didik berdasarkan kunci jawaban dan pedoman penskoran yang telah dibuat dan divalidasi oleh peneliti.

\section{HASIL DAN PEMBAHASAN}

Profil produk e-magazine yang diperoleh pada penelitian pengembangan ini sesuai dengan karakteristik e-magazine sebagai berikut:

1. E-magazine reaksi reduksi dan oksidasi dikembangkan untuk mempermudah dan memotivasi peserta didik Kelas $\mathrm{X}$ dalam mempelajari materi reaksi reduksi dan oksidasi secara efektif dan mandiri. Emagazine reaksi reduksi dan oksidasi dikembangkan digunakan oleh guru sebagai media yang dapat menunjang proses pembelajaran di kelas $\mathrm{X}$ terlebih jika pembelajaran secara daring sehingga pembelajaran lebih efektif.

2. Sampul e-magazine yang menarik

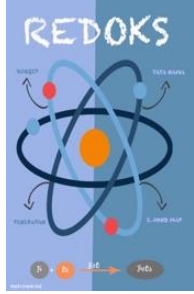

Gambar 1. Sampul e-magazine

3. Materi atau isi e-magazine singkat agar mudah dimengerti

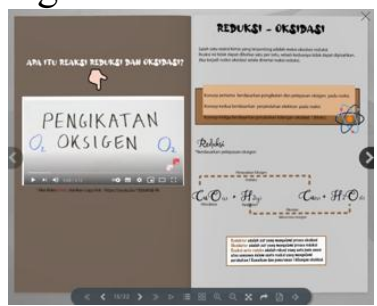

Gambar 2. Materi atau isi e-magazine

4. Penyajian konten yang menarik untuk pembaca

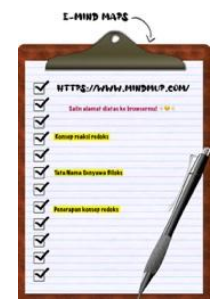

Gambar 3. Konten pembuatan mindmap

Pada halaman terakhir e-magazine terdapat ruang bagi peserta didik untuk memetakan pikirannya. E-magazine yang dikembangkan diperoleh dengan menggunakan model pengembangan ADDIE dengan tahap yang dijabarkan sebagai berikut:

\section{Tahap Analisis (Analysis)}

Pada tahap ini dilakukan analisis kinerja, analisis karakteristik peserta didik, dan kajian literatur yang diperoleh melalui observasi dan wawancara dengan guru mata pelajaran kimia di SMAN 9 Jeneponto dan diperoleh kendala sebagai berikut:

a. Penyesuaian waktu pembelajaran berdasarkan kurikulum darurat pada masa pandemi dikarenakan diberlakukannya 
belajar dari rumah (daring) menjadi 60 menit dengan 1 kali pertemuan setiap minggu menggunakan aplikasi google classroom dan group whatsapp.

b. Media pembelajaran yang digunakan oleh guru hanya berupa power point dan $e$-book.

c. Banyak peserta didik yang terkendala pada jaringan internet sehingga mengganggu proses pembelajaran

Pada analisis kajian literatur terhadap teori dan beberapa penelitian terdahulu yang relevan maka diperoleh kurangnya pemahaman materi peserta didik sebelumnya pada materi reaksi reduksi dan oksidasi yang merupakan salah satu materi yang mencakup pemahaman konsep istilah dan angka. Berdasarkan penelitian (Annisa \& Soeling, 2013) tingkat kesulitan peserta didik dalam memahami konsep pada materi reaksi reduksi dan oksidasi sangat tinggi sebesar $46,78 \%$.

Analisis kinerja, analisis karakteristik peserta didik, dan kajian literatur dilakukan dengan menganalisis faktor-faktor yang menimbulkan permasalahan. Sehingga perlu ada pengembangan media baru yang dirancang berdasarkan analisis masalah yang diperoleh.

\section{Tahap Perancangan (Design)}

Pada tahap ini meliputi beberapa perencanaan pengembangan produk $e$ magazine yaitu penentuan standar kompetensi, kompetensi dasar dan indikator yang akan digunakan dalam pembuatan $e$ magazine sebagai media solusi dari kendala yang diperoleh pada tahap analisis. Selanjutnya dilakukan pembuatan sketsa desain produk e-magazine reaksi reduksi dan oksidasi dan pembuatan kisi-kisi instrumen penilaian untuk mengetahui kriteria kualitas produk e-magazine.

\section{Tahap Pengembangan (Development)}

Tahap pengembangan awal (development) e-magazine dilakukan setelah tahap perancangan dan penentuan konten (isi) dari e-magazine dengan tujuan yang perlu dicapai yaitu e-magazine yang dikembangkan dibuat dan dimodifikasi agar memenuhi tujuan pembelajaran. Pada tahap pengembangan dilakukan validasi ahli media dan ahli materi setelah dihasilkan produk $e$ magazine.

a. Validasi Ahli Materi

Hasil validasi pada ahli materi diperoleh bahwa media e-magazine dapat digunakan untuk uji coba lapangan awal dengan syarat revisi sesuai saran/masukan. Beberapa saran perbaikan dari para ahli materi yaitu:

1. Masih perlu tambahan konten, contohcontoh reaksi pada setiap konsep reaksi reduksi dan oksidasi.

2. Perbaikan pada persamaan reaksi kimia semua ditulis biasa saja. Sebab ada reaksi $\mathrm{CuO}+\mathrm{H}_{2}$ yang ditulis dengan font yang lain boleh jadi membuat pembacaan peserta didik berbeda-beda.

3. Penambahan contoh soal dan soal latihan lebih divariasi dan diinovasi.

Hasil angket validator 1 memberikan skor 3 pada sebagian besar aspek penilaian namun pada aspek isi materi yaitu penyampaian isi yang berurut diberikan skor 4 . Validator 2 juga memberikan skor 3 pada sebagian besar aspek penilaian namun pada aspek isi materi yaitu penyampaian isi yang berurut dan kebenaran konsep materi diberikan skor 4 . Hasil akhir analisis penilaian ahli materi menunjukkan nilai validitas sebesar 1,00 sesuai dengan kriteria validitas menurut Gregory, maka nilai tersebut berada pada kriteria sangat tinggi.

b. Validasi ahli media

Hasil validasi pada ahli media diperoleh bahwa media e-magazine dapat digunakan untuk uji coba lapangan awal dengan syarat revisi sesuai saran/masukan. Beberapa saran perbaikan dari para ahli materi yaitu :

1. Kesalahan grammar seharusnya "How Science Works"

2. Keterbacaan huruf kurang jelas, font dan style bisa dipilih yang lebih jelas sehingga keterbacaan jelas.

3. Font untuk penulisan reaksi ditulis biasa agar keterbacaan jelas.

4. Sematkan link video pembelajaran untuk memperkaya konten e-magazine.

Hasil angket validator ahli media menunjukkan bahwa aspek tampilan desain cover memberikan kesan positif sehingga mampu menarik minat pembaca dari setiap 
ahli memberikan skor 4 dan memberikan skor 3 pada sebagian besar aspek penilaian namun pada keterbacaan teks dua ahli memberikan skor 2. Hasil akhir analisis penilaian ahli media menunjukkan nilai validitas sebesar 1,00 sesuai dengan kriteria kevalidan menurut menurut Gregory, maka nilai tersebut berada pada kriteria sangat tinggi.

\section{Tahap Implementasi (Implementation)}

Tahap implementasi dilaksanakan apabila media e-magazine telah tervalidasi untuk digunakan pada pembelajaran, pada tahap ini dilakukan uji coba lapangan awal yang merupakan tahap untuk mengetahui layak atau tidak media e-magazine yang dikembangkan digunakan dalam pembelajaran. Uji coba lapangan awal dilakukan pada tanggal 11 februari 2021 terhadap 9 orang peserta didik kelas X MIA 2 SMAN 9 Jeneponto. Uji coba lapangan awal dilakukan dengan bentuk penelitian one-shot case study hasil post-test peserta didik yang dapat dilihat pada tabel 4.3.

Tabel 7. Rekapitulasi Hasil Post-test peserta didik pada uji lapangan awal

\begin{tabular}{cc}
\hline & Tes Evaluasi \\
\hline Nilai Rata-Rata & 80 \\
\hline Jumlah Peserta Didik Tuntas & 7 orang \\
\hline $\begin{array}{c}\text { Jumlah Peserta Didik Tidak } \\
\text { Tuntas }\end{array}$ & 2 orang \\
\hline $\begin{array}{c}\text { Persentase Ketuntasan Peserta } \\
\text { Didik }\end{array}$ & $77,78 \%$ \\
\hline
\end{tabular}

Tabel 7 menunjukkan bahwa persentase ketuntasan dari 9 orang peserta didik pada post test dengan persentase ketuntasan sebesar $77,78 \%$. Namun, terdapat 2 orang peserta didik yang memiliki nilai dibawah standar ketuntasan dengan nilai 72 dan 74. Tahapan ini juga dilakukan pengisian angket oleh guru mata pelajaran kimia dan peserta didik untuk mengetahui bagaimana kepraktisan media $e$ magazine yang dikembangkan pada uji coba lapangan awal. Hasil analisis angket respon guru diperoleh bahwa media e-magazine dapat digunakan untuk uji coba lapangan awal dengan beberapa saran perbaikan yaitu :

1. E-magazine yang dirancang tidak hanya dapat dibuka pada android tapi bisa juga pada PC sehingga lebih memudahkan peserta didik untuk mengakses media tersebut.
2. Diusahakan semaksimal mungkin video atau web yang terdapat dalam e-magazine dapat terputar otomatis (tanpa kendala) sehingga peserta didik tidak perlu lagi mengcopy link web tersebut kemudian membukanya pada tab lain.

3. Memberikan masukan materi pada langkah-langkah penentuan bilangan oksidasi.

Tabel 8. Rekapitulasi Angket Respon Guru Mata Pelajaran Uji Coba Lapangan Awal

\begin{tabular}{|c|c|c|c|}
\hline No. & KRITERIA & SKOR & $\begin{array}{c}\text { NILAI } \\
(\%)\end{array}$ \\
\hline 1. & $\begin{array}{l}\text { Respon guru } \\
\text { Kesesuaian indikator } \\
\text { dengan tingkat } \\
\text { perkembangan peserta } \\
\text { didik }\end{array}$ & 4 & 100 \\
\hline 2. & $\begin{array}{l}\text { Kesesuaian materi yang } \\
\text { relevan dengan KI dan } \\
\text { KD }\end{array}$ & 4 & 100 \\
\hline 3. & $\begin{array}{l}\text { Kualitas media sudah } \\
\text { memenuhi media } \\
\text { pembelajaran }\end{array}$ & 3 & 75 \\
\hline 4. & $\begin{array}{l}\text { Penggunaan media yang } \\
\text { dikembangkan } \\
\text { memenuhi fungsi praktis }\end{array}$ & 4 & 100 \\
\hline 5. & $\begin{array}{l}\text { Desain media baik } \\
\text { (kejelasan huruf, gambar } \\
\text { dan background) }\end{array}$ & 3 & 75 \\
\hline 6. & $\begin{array}{l}\text { Tingkat interaktivitas } \\
\text { peserta didik dengan } \\
\text { media. }\end{array}$ & 3 & 75 \\
\hline 7. & $\begin{array}{l}\text { Media dapat digunakan } \\
\text { di berbagai tempat, } \\
\text { waktu keadaan. }\end{array}$ & 4 & 100 \\
\hline 8. & $\begin{array}{l}\text { Media pembelajaran ini } \\
\text { dapat menjadi alternatif } \\
\text { sumber belajar yang } \\
\text { menyenangkan bagi } \\
\text { peserta didik }\end{array}$ & 4 & 100 \\
\hline 9. & $\begin{array}{l}\text { Media dapat melatih } \\
\text { kemandirian belajar } \\
\text { peserta didik }\end{array}$ & 4 & 100 \\
\hline 10. & $\begin{array}{l}\text { Kemudahan dalam } \\
\text { penggunaan media }\end{array}$ & 3 & 75 \\
\hline 11. & $\begin{array}{l}\text { Tampilan umum media } \\
\text { menarik }\end{array}$ & 4 & 100 \\
\hline & Jumlah & & 1000 \\
\hline & Rata-rata & & 90,90 \\
\hline & Kriteria & & $\begin{array}{l}\text { Sangat } \\
\text { Praktis }\end{array}$ \\
\hline
\end{tabular}

Tabel 8 menunjukkan bahwa respon guru mata pelajaran skor 3-4 pada setiap aspek. Hasil akhir analisis respon guru mata 
pelajaran terhadap e-magazine menunjukkan nilai sebesar 90,90\% sesuai dengan kriteria kepraktisan menurut Riduwan, maka nilai tersebut berada pada kriteria sangat praktis.

Tabel 9. Rekapitulasi Angket Respon Peserta Didik Uji Coba Lapangan Awal

\begin{tabular}{|c|c|c|c|c|c|c|}
\hline \multirow[t]{2}{*}{ KRITERIA } & \multicolumn{4}{|c|}{ SKOR } & \multirow{2}{*}{$\begin{array}{l}\text { Skor } \\
\text { total } \\
\end{array}$} & \multirow{2}{*}{$\begin{array}{l}\text { Nilai } \\
(\%)\end{array}$} \\
\hline & 1 & 2 & 3 & 4 & & \\
\hline $\begin{array}{l}\text { Respon peserta } \\
\text { didik } \\
\text { Media yang } \\
\text { dikembangkan } \\
\text { mudah } \\
\text { digunakan }\end{array}$ & 0 & 0 & 8 & 1 & 28 & 78 \\
\hline $\begin{array}{l}\text { Media dapat } \\
\text { digunakan di } \\
\text { berbagai tempat, } \\
\text { waktu keadaan. }\end{array}$ & 0 & 0 & 7 & 2 & 29 & 80 \\
\hline $\begin{array}{l}\text { Media } e \text { - } \\
\text { magazine } \\
\text { mempermudah } \\
\text { untuk } \\
\text { menambah } \\
\text { pengetahuan dan } \\
\text { memahami } \\
\text { peserta didik } \\
\text { tentang materi } \\
\text { reaksi reduksi } \\
\text { dan oksidasi } \\
\text { kelas X }\end{array}$ & 0 & 2 & 6 & 1 & 26 & 72 \\
\hline $\begin{array}{l}\text { Media } e \text { - } \\
\text { magazine dapat } \\
\text { membantu } \\
\text { peserta didik } \\
\text { untuk belajar } \\
\text { secara aktif dan } \\
\text { mandiri. }\end{array}$ & 0 & 0 & 5 & 4 & 31 & 86 \\
\hline $\begin{array}{l}\text { Setelah adanya } \\
\text { media } e \text { - } \\
\text { magazine minat } \\
\text { belajar menjadi } \\
\text { lebih tinggi. }\end{array}$ & 0 & 2 & 5 & 2 & 27 & 75 \\
\hline $\begin{array}{l}\text { Tampilan setiap } \\
\text { slide media } e- \\
\text { magazine } \\
\text { memiliki } \\
\text { komposisi } \\
\text { gambar dan } \\
\text { warna yang } \\
\text { serasi. }\end{array}$ & 0 & 3 & 3 & 3 & 27 & 75 \\
\hline $\begin{array}{l}\text { Media } e \text { - } \\
\text { magazine } \\
\text { menggunakan } \\
\text { bahasa yang } \\
\text { komunikatif } \\
\text { sehingga mudah } \\
\text { dipahami. }\end{array}$ & 0 & 2 & 6 & 1 & 26 & 72 \\
\hline
\end{tabular}

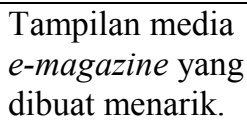

\begin{tabular}{cc}
\hline Jumlah & 638 \\
\hline Rata-rata & $\mathbf{7 9 , 7 5}$ \\
\hline Kriteria & Praktis \\
\hline
\end{tabular}

Sedangkan untuk hasil angket respon peserta didik terhadap e-magazine pada uji coba lapangan awal, menunjukkan respon dengan rata-rata nilai sebesar 79,75\%. Hal tersebut menunjukkan bahwa respon peserta didik terhadap e-magazine sehingga $e$ magazine dapat diuji coba lapangan utama.

Kegiatan yang dilakukan setelah melakukan revisi dari uji coba lapangan awal, selanjutnya dilakukan uji coba lapangan utama. Pada uji coba lapangan utama kelas X MIA 3 sama dengan kegiatan yang dilakukan pada uji coba lapangan awal yang membedakan hanya pada jumlah sampel dan media $e$-magazine yang telah direvisi.

Tabel 10. Rekapitulasi Hasil Post-test Peserta Didik pada Uji Coba Lapangan Utama

\begin{tabular}{lc}
\hline & Post-test \\
\hline Nilai Rata-rata & 83,33 \\
Jumlah Peserta Didik Tuntas & 26 \\
Jumlah Peserta Didik Tidak Tuntas & 4 \\
Persentase Ketuntasan Peserta & $86,67 \%$ \\
Didik & \\
\hline
\end{tabular}

Tabel 10 menunjukkan ketuntasan dari 30 peserta didik pada uji coba lapangan utama dengan persentase ketuntasan sebesar $86,67 \%$ terdapat 4 peserta didik yang tidak tuntas karena memiliki nilai post-test dengan rentang 68-72 atau dibawah nilai KKM yang diberikan oleh guru yaitu 75 . Seperti halnya pada uji coba lapangan awal pada akhir pembelajaran dilakukan ujian evaluasi (post test) untuk mengetahui keefektifan $e$ magazine dan pengisian angket respon guru dan peserta didik untuk mengetahui kepraktisan e-magazine.

Tabel 11. Rekapitulasi Angket Respon Guru Uji Coba Lapangan Utama

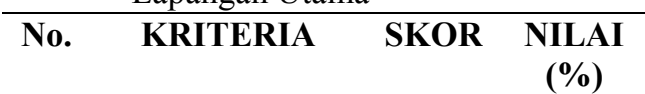


Maipha Deapati Arief, Army Auliah dan Hardin

Jurnal Inovasi Pembelajaran Kimia (ournal Of Innovation in Chemistry Education) Volume 3, Nomor 2, Oktober 2021 Pengembangan E-Magazine Reaksi Reduksi dan Oksidasi Sebagai Media Pembelajaran Kimia Kelas X SMA/MA

\begin{tabular}{|c|c|c|c|}
\hline 1. & $\begin{array}{l}\text { Respon guru } \\
\text { Kesesuaian } \\
\text { indikator dengan } \\
\text { tingkat } \\
\text { perkembangan } \\
\text { peserta didik }\end{array}$ & 4 & 100 \\
\hline 2. & $\begin{array}{l}\text { Kesesuaian } \\
\text { materi yang } \\
\text { relevan dengan } \\
\text { KI dan KD }\end{array}$ & 4 & 100 \\
\hline 3. & $\begin{array}{l}\text { Kualitas media } \\
\text { sudah memenuhi } \\
\text { media } \\
\text { pembelajaran }\end{array}$ & 3 & 75 \\
\hline 4. & $\begin{array}{l}\text { Penggunaan } \\
\text { media yang } \\
\text { dikembangkan } \\
\text { memenuhi } \\
\text { fungsi praktis }\end{array}$ & 4 & 100 \\
\hline 5. & $\begin{array}{l}\text { Desain media } \\
\text { baik (kejelasan } \\
\text { huruf, gambar } \\
\text { dan background) }\end{array}$ & 4 & 100 \\
\hline 6. & $\begin{array}{l}\text { Tingkat } \\
\text { interaktivitas } \\
\text { peserta didik } \\
\text { dengan media. }\end{array}$ & 3 & 75 \\
\hline 7. & $\begin{array}{l}\text { Media dapat } \\
\text { digunakan di } \\
\text { berbagai tempat, } \\
\text { waktu keadaan. }\end{array}$ & 4 & 100 \\
\hline 8. & $\begin{array}{l}\text { Media } \\
\text { pembelajaran ini } \\
\text { dapat menjadi } \\
\text { alternatif sumber } \\
\text { belajar yang } \\
\text { menyenangkan } \\
\text { bagi peserta } \\
\text { didik }\end{array}$ & 4 & 100 \\
\hline 9. & $\begin{array}{l}\text { Media dapat } \\
\text { melatih } \\
\text { kemandirian } \\
\text { belajar peserta } \\
\text { didik }\end{array}$ & 4 & 100 \\
\hline 10. & $\begin{array}{l}\text { Kemudahan } \\
\text { dalam } \\
\text { penggunaan } \\
\text { media }\end{array}$ & 4 & 100 \\
\hline 11. & $\begin{array}{l}\text { Tampilan umum } \\
\text { media menarik }\end{array}$ & 4 & 100 \\
\hline & $\begin{array}{c}\text { Jumlah } \\
\text { Rata-rata } \\
\text { Kriteria }\end{array}$ & & $\begin{array}{l}1050 \\
95,45 \\
\text { Sangat } \\
\text { Praktis }\end{array}$ \\
\hline
\end{tabular}

Tabel 12. Rekapitulasi Angket Respon Peserta Didik Uji Coba Lapangan Utama

\begin{tabular}{cccc} 
KRITERIA & SKOR & $\begin{array}{l}\text { Skor } \\
\text { total }\end{array}$ & $\begin{array}{c}\text { Nilai } \\
(\%)\end{array}$ \\
\hline
\end{tabular}

\begin{tabular}{|c|c|c|c|c|c|c|}
\hline & 1 & 2 & 3 & 4 & & \\
\hline $\begin{array}{l}\text { Respon peserta } \\
\text { didik } \\
\text { Media yang } \\
\text { dikembangkan } \\
\text { mudah digunakan }\end{array}$ & 0 & 0 & 19 & 11 & 101 & 84 \\
\hline $\begin{array}{l}\text { Media dapat } \\
\text { digunakan di } \\
\text { berbagai tempat, } \\
\text { waktu keadaan. }\end{array}$ & 0 & 0 & 25 & 5 & 95 & 79 \\
\hline $\begin{array}{l}\text { Media e-magazine } \\
\text { mempermudah } \\
\text { untuk menambah } \\
\text { pengetahuan dan } \\
\text { memahami peserta } \\
\text { didik tentang } \\
\text { materi reaksi } \\
\text { reduksi dan } \\
\text { oksidasi kelas X }\end{array}$ & 0 & 2 & 20 & 8 & 96 & 80 \\
\hline $\begin{array}{l}\text { Media e-magazine } \\
\text { dapat membantu } \\
\text { peserta didik } \\
\text { untuk belajar } \\
\text { secara aktif dan } \\
\text { mandiri. }\end{array}$ & 0 & 0 & 26 & 4 & 94 & 78 \\
\hline $\begin{array}{l}\text { Setelah adanya } \\
\text { media e-magazine } \\
\text { minat belajar } \\
\text { menjadi lebih } \\
\text { tinggi. }\end{array}$ & 0 & 2 & 18 & 10 & 98 & 81 \\
\hline $\begin{array}{l}\text { Tampilan setiap } \\
\text { slide media } e \text { - } \\
\text { magazine } \\
\text { memiliki } \\
\text { komposisi gambar } \\
\text { dan warna yang } \\
\text { serasi. }\end{array}$ & 0 & 0 & 13 & 17 & 107 & 89 \\
\hline $\begin{array}{l}\text { Media e-magazine } \\
\text { menggunakan } \\
\text { bahasa yang } \\
\text { komunikatif } \\
\text { sehingga mudah } \\
\text { dipahami. }\end{array}$ & 0 & 0 & 3 & 27 & 117 & 97 \\
\hline $\begin{array}{l}\text { Tampilan media } e- \\
\text { magazine yang } \\
\text { dibuat menarik. }\end{array}$ & 0 & 0 & 4 & 26 & 116 & 96 \\
\hline \multicolumn{6}{|c|}{$\begin{array}{c}\text { Jumlah } \\
\text { Rata-rata } \\
\text { Kriteria }\end{array}$} & $\begin{array}{c}684 \\
85,5 \\
\text { Sangat } \\
\text { Praktis }\end{array}$ \\
\hline
\end{tabular}

\section{Tahap Evaluasi (Evaluation)}


Pada tahap ini dilakukan evaluasi awal media e-magazine setelah uji coba lapangan awal dengan evaluasi sebagai berikut :

Tabel 13. Rekapitulasi Saran Guru dan Peserta Didik Uji Coba Lapangan Awal

\begin{tabular}{|c|c|c|c|}
\hline \multirow{3}{*}{$\begin{array}{l}\text { No. } \\
1 .\end{array}$} & Responden & Saran & Revisi \\
\hline & Guru & $\begin{array}{l}\text { 1. E-magazine } \\
\text { yang } \\
\text { dikembangkan } \\
\text { selain dapat } \\
\text { diakses pada } \\
\text { Handphone tetapi } \\
\text { dapat juga dikases } \\
\text { di komputer. }\end{array}$ & \\
\hline & & $\begin{array}{l}\text { 2. Video } \\
\text { pembelajaran } \\
\text { pada } e \text {-magazine } \\
\text { dapat terbuka } \\
\text { dengan mudah } \\
\text { tanpa disalin link } \\
\text { video. }\end{array}$ & $\begin{array}{l}\text { PENGIKATAN } \\
\text { OKSIGEN Oa }\end{array}$ \\
\hline 2. & $\begin{array}{l}\text { Peserta } \\
\text { Didik }\end{array}$ & $\begin{array}{l}\text { 1. Bahasa yang } \\
\text { digunakan mudah } \\
\text { untuk dipahami } \\
\text { 2. E-magazine } \\
\text { menarik sehingga } \\
\text { dapat memotivasi } \\
\text { saya dalam } \\
\text { belajar }\end{array}$ & \\
\hline
\end{tabular}

Pada tahap uji coba lapangan utama juga dilakukan evaluasi media untuk mengetahui hasil akhir dari media e-magazine yang dikembangkan. Namun, pada tahap ini tidak dilakukan revisi produk II karena hanya terdapat saran atau komentar positif tentang media $e$-magazine yang dikembangkan.

Tabel 14. Rekapitulasi Hasil Respon Guru dan Peserta Didik Pada Uji Coba Lapangan Utama

\begin{tabular}{|c|c|c|c|}
\hline No & Responden & Saran & Revisi \\
\hline 1. & Guru & $\begin{array}{l}\text { Media e-magazine } \\
\text { secara } \\
\text { keseluruhan sudah } \\
\text { baik digunakan } \\
\text { sebagai media } \\
\text { dalam } \\
\text { pembelajaran. }\end{array}$ & \\
\hline 2. & Peserta Didik & $\begin{array}{l}\text { 1. E-magazine } \\
\text { menarik untuk } \\
\text { dipelajari } \\
\text { 2. Konten } e \text { - } \\
\text { magazine lebih } \\
\text { mudah untuk } \\
\text { dipahami } \\
\text { 3. Menggunakan } \\
\text { Bahasa yang } \\
\text { mudah dimengerti }\end{array}$ & \\
\hline
\end{tabular}

\section{DISKUSI}

Penelitian ini bertujuan untuk mengembangkan produk dan menghasilkan produk media e-magazine materi reaksi reduksi dan oksidasi yang valid, praktis, dan efektif yang digunakan sebagai media pembelajaran dan dapat membantu guru dan peserta didik mengatasi kesulitan dan pemahaman konsep dalam proses pembelajaran. Penelitian pengembangan ini menggunakan model pengembangan ADDIE yang dimodifikasi sesuai kebutuhan penelitian.

Analisis dilakukan pada media pembelajaran materi kimia kelas $\mathrm{X}$ semester genap tahun ajaran 2020/2021 pada materi reaksi reduksi oksidasi. Berdasarkan latar belakang masalah yang diperoleh yaitu media pembelajaran yang dirancang sesuai dengan keadaan kebutuhan peserta didik, seperti permasalahan dunia saat ini yang sedang mengalami pandemi Covid-19, sehingga diterapkan social distancing untuk seluruh kegiatan sosial maupun pendidikan yang mengharuskan adanya pembelajaran jarak jauh (daring) sehingga untuk mencapai kompetensi pembelajaran dapat dilakukan dengan beberapa kegiatan belajar, salah satunya dengan memberikan media belajar mandiri kepada peserta didik agar minat belajar peserta didik meningkat. Telaah Kompetensi Inti (KI) dan Kompetensi Dasar (KD) juga dilakukan dalam tahap ini yang akan dijadikan sebagai acuan dalam mengembangkan e-magazine materi reaksi reduksi dan oksidasi dengan penyesuaian indikator pembelajaran pada e-magazine yang akan dikembangkan.

Tabel 15. Kompetensi Dasar (KD) dan Indikator Pembelajaran Mata Pelajaran Kimia Kelas X Semester 2

\begin{tabular}{|c|c|}
\hline $\begin{array}{c}\text { KOMPETENSI } \\
\text { DASAR }\end{array}$ & $\begin{array}{c}\text { INDIKATOR } \\
\text { PEMBELAJARAN }\end{array}$ \\
\hline 3.9 Mengidentifikasi & 1. Membedakan konsep \\
\hline reaksi reduksi dan & reduksi dan oksidasi \\
\hline oksidasi menggunakan & ditinjau dari \\
\hline konsep bilangan & penggabungan dan \\
\hline oksidasi unsur & pelepasan oksigen, \\
\hline $\begin{array}{l}\text { 4.9 Menganalisis } \\
\text { beberapa reaksi } \\
\text { berdasarkan perubahan }\end{array}$ & $\begin{array}{l}\text { penerimaan elektron, } \\
\text { serta peningkatan dan }\end{array}$ \\
\hline
\end{tabular}


bilangan oksidasi yang penurunan bilangan diperoleh dari data hasil percobaan dan/atau melalui percobaan

oksidasi.
2. Menentukan bilangan oksidasi atom unsur dalam senyawa atau ion.

3. Menentukan oksidator dan reduktor dalam reaksi reduksi dan oksidasi.

4. Menuliskan tata nama senyawa berdasarkan harga bilangan oksidasi logam pembentuknya.

Berdasarkan peraturan menteri Pendidikan No. 22 Tahun 2006 tentang standar isi, mata pelajaran kimia di SMA menekankan penguasaan konsep abstrak maka dari itu peserta didik diberikan media pembelajaran yang meningkatkan minat belajar mandiri peserta didik. Media pembelajaran dikategorikan baik apabila memenuhi tiga fungsi yaitu:

a. Fungsi stimulasi yang menimbulkan ketertarikan pada media

b. Fungsi mediasi yang merupakan perantara komunikasi antara guru dan peserta didik.

c. Fungsi informasi yang dapat memudahkan peserta didik untuk menangkap penjelasan yang disampaikan oleh guru.

Pada tahap ini identifikasi masalah dilakukan untuk menganalisis faktor-faktor yang menimbulkan permasalahan sehingga dilakukan pengembangan produk baru dengan melakukan observasi di SMAN 9 Jeneponto, kegiatan observasi ini juga dilengkapi dengan wawancara terhadap guru mata pelajaran kimia yang dilakukan secara langsung. Adapun masalah yang teridentifikasi yaitu:

a. Pengurangan durasi waktu pembelajaran pada masa pandemi dikarenakan diberlakukannya belajar dari rumah (daring) menjadi 60 menit dengan 1 kali pertemuan setiap minggu menggunakan aplikasi google classroom, group whatsapp, dan google meet.

b. Media pembelajaran yang digunakan oleh guru hanya berupa power point dan e-book.

c. Banyak peserta didik yang terkendala pada jaringan internet sehingga mengganggu proses pembelajaran yang mengakibatkan kurangnya minat belajar peserta didik khusus pada materi reaksi reduksi dan oksidasi karena pemahaman konsep peserta didik yang kurang.

d. Peserta didik memiliki minat baca yang cukup tinggi namun bacaan yang dibaca bersifat non-fiksi (novel dan komik bergambar)

Setelah mengidentifikasi masalah, peneliti menganalisis solusi untuk menyelesaikan permasalahan tersebut proses rancangan pengembangan awal e-magazine dilakukan sesuai dengan prosedur pengembangan yang telah ditempuh yang menghasilkan produk awal dengan judul " $E$ Magazine Kimia Materi Reaksi Reduksi Oksidasi" yang berisi materi reaksi reduksi dan oksidasi sesuai kompetensi dasar dan indikator pembelajaran yang telah disesuaikan.

Tahap ini dilakukan validasi ahli atau pakar terhadap produk awal e-magazine untuk mengetahui kekurangan serta perbaikan yang perlu dilakukan sebelum e-magazine diuji coba. Validasi dilakukan oleh 3 dosen dengan spesifikasi 2 dosen ahli materi dan 2 dosen ahli media.

a. Validasi ahli materi

Hasil validasi pada ahli materi diperoleh bahwa media e-magazine dapat digunakan untuk uji coba lapangan awal dengan syarat revisi Tabel 4.1 menunjukkan bahwa validator 1 memberikan skor 3 pada sebagian besar aspek penilaian namun pada aspek isi materi yaitu penyampaian isi yang berurut diberikan skor 4 . Validator 2 juga memberikan skor 3 pada sebagian besar aspek penilaian namun pada aspek isi materi yaitu penyampaian isi yang berurut dan kebenaran konsep materi diberikan skor 4. Hasil akhir analisis penilaian ahli materi menunjukkan nilai validitas sebesar 1,00 sesuai dengan kriteria kevalidan menurut Gregory, maka nilai tersebut berada pada kriteria sangat tinggi.

b. Validasi ahli media

Hasil validasi pada ahli media diperoleh bahwa media e-magazine dapat digunakan untuk uji coba lapangan awal dengan syarat revisi tabel 6 menunjukkan bahwa aspek tampilan desain cover memberikan kesan positif sehingga mampu menarik minat pembaca dari setiap ahli memberikan skor 4 
dan memberikan skor 3 pada sebagian besar aspek penilaian namun pada keterbacaan teks dua ahli memberikan skor 2. Hasil akhir analisis penilaian ahli media menunjukkan nilai validitas sebesar 1,00 sesuai dengan kriteria kevalidan menurut menurut Gregory, maka nilai tersebut berada pada kriteria sangat tinggi.

Media e-magazine dikatakan valid apabila koefisien validitas e-magazine lebih besar dari 0,60 (Nur et al., 2012). Secara umum e-magazine yang dikembangkan telah memenuhi aspek kevalidan dengan hasil 1,00 yang tergolong sangat tinggi dan dapat digunakan untuk uji coba lapangan awal dengan syarat revisi sesuai saran/masukan. Media e-magazine sebagai salah satu bahan ajar yang dapat digunakan dalam proses pembelajaran haruslah memiliki validitas yang baik agar tujuan pembelajaran dapat tercapai.

Uji coba lapangan awal merupakan tahap yang dilakukan untuk mengetahui layak atau tidak media e-magazine yang dikembangkan digunakan dalam pembelajaran. Uji coba lapangan awal dilakukan pada tanggal 11 februari 2021 terhadap 9 orang peserta didik kelas X MIA 2 SMAN 9 Jeneponto. Uji coba lapangan awal dilakukan dengan bentuk penelitian one-shot case study. Hasil pembelajaran pada uji coba lapangan awal ini memperlihatkan peserta didik fokus dengan apresepsi yang diberikan sehingga termotivasi untuk mempelajari materi reaksi reduksioksidasi. Media e-magazine digunakan selama pembelajaran materi reaksi reduksi dan oksidasi setelah pembelajaran peserta didik diarahkan untuk mengerjakan soal evaluasi yang sebelumnya telah divalidasi oleh ahli materi untuk mengetahui keefektifan media e-magazine yang digunakan dalam pembelajaran pada uji coba lapangan awal. Analisis keefektifan dilakukan dengan menganalisis nilai hasil post-test peserta didik yang dijadikan subjek uji coba lapangan awal dengan rekapitulasi hasil belajar peserta didik dapat dilihat pada tabel 7 .

Tabel 7 menunjukkan bahwa persentase ketuntasan dari 9 orang peserta didik pada tes evaluasi dengan persentase ketuntasan sebesar
$88,89 \%$. Namun, terdapat 1 orang peserta didik yang memiliki nilai tes evaluasi di bawah standar ketuntasan dengan nilai 74 . Hal tersebut dikarenakan peserta didik kurang teliti dalam memahami maksud dari soal evaluasi terkhususnya pada soal nomor 1 yaitu penjelasan konsep perkembangan reaksi reduksi dan oksidasi namun peserta didik hanya menuliskan tiga perkembangan konsep redoks tanpa memberikan penjelasan. media e-magazine yang dikembangkan dapat dikatakan efektif apabila jika hasil tes evaluasi menunjukkan persentase lebih besar sama dengan 65\% (Nur et al., 2012). Dari hasil tersebut dapat disimpulkan bahwa e-magazine yang dikembangkan efektif.

Tahapan ini juga dilakukan pengisian angket oleh guru mata pelajaran kimia dan peserta didik untuk mengetahui bagaimana kepraktisan media e-magazine yang dikembangkan pada uji coba lapangan awal. Hasil analisis angket respon guru diperoleh bahwa media e-magazine dapat digunakan untuk uji coba lapangan awal dengan beberapa saran perbaikan yaitu :

1. E-magazine yang dirancang tidak hanya dapat dibuka pada android tapi bisa juga pada PC sehingga lebih memudahkan peserta didik untuk mengakses media tersebut.

2. Diusahakan semaksimal mungkin video atau web yang terdapat dalam e-magazine dapat terputar otomatis (tanpa kendala) sehingga peserta didik tidak perlu lagi mengcopy link web tersebut kemudian membukanya pada tab lain.

3. Memberikan masukan materi pada langkah-langkah penentuan bilangan oksidasi.

Tabel 8 menunjukkan bahwa respon guru mata pelajaran skor 3-4 pada setiap aspek. Hasil akhir analisis respon guru mata pelajaran terhadap e-magazine menunjukkan nilai sebesar $90,90 \%$ sesuai dengan kriteria kepraktisan menurut Riduwan, maka nilai tersebut berada pada kriteria sangat praktis sama halnya dengan hasil angket respon peserta didik terhadap e-magazine untuk uji coba lapangan awal, menunjukkan respon dengan rata-rata nilai sebesar $79,75 \%$. Hal tersebut menunjukkan bahwa respon peserta 
didik terhadap e-magazine sehingga $e$ magazine dapat diuji coba lapangan utama.

Tabel 16. Rekapitulasi Hasil Angket Respon Guru dan Peserta Didik Uji Coba Lapangan Awal

\begin{tabular}{ccc}
\hline & \multicolumn{2}{c}{ Nilai Respon } \\
\hline & Guru & Peserta Didik \\
\hline $\begin{array}{c}\text { Uji Coba } \\
\text { Lapangan } \\
\text { Awal }\end{array}$ & $\mathbf{9 0 , 9 0 \%}$ & $\mathbf{7 9 , 7 5 \%}$ \\
\hline
\end{tabular}

Tahapan ini dilakukan untuk merevisi berdasarkan hasil analisis yang dilakukan pada uji coba lapangan awal yaitu berdasarkan analisis hasil belajar peserta didik, analisis saran yang diberikan oleh guru dan peserta didik terhadap e-magazine. Berdasarkan analisis hasil belajar peserta didik pada uji coba lapangan awal bahwa media e-magazine yang dikembangkan telah memenuhi aspek keefektifan dan telah memenuhi aspek kepraktisan berdasarkan analisis angket respon guru dan peserta didik dengan beberapa saran. Rekapitulasi saran tersebut dapat dilihat pada tabel 13 Berdasarkan respon guru dan peserta didik pada uji coba lapangan awal dan telah dilakukan revisi berdasarkan saran yang diperoleh maka media e-magazine layak digunakan pada tahap uji coba lapangan utama.

Uji coba lapangan utama bertujuan untuk mengetahui sejauh mana e-magazine yang diperoleh dapat mencapai sasaran dan tujuan. Uji coba lapangan utama dilakukan pada tanggal 3 maret 2021 terhadap 30 orang peserta didik kelas X MIA 3 di SMAN 9 Jeneponto. Kegiatan yang dilakukan pada uji coba lapangan utama kelas X MIA 3 sama dengan kegiatan yang dilakukan pada uji coba lapangan awal yang membedakan hanya pada jumlah sampel dan media e-magazine yang telah direvisi, seperti halnya pada uji coba lapangan awal pada akhir pembelajaran dilakukan ujian evaluasi untuk mengetahui keefektifan $e$-magazine dan pengisian angket respon guru dan peserta didik untuk mengetahui kepraktisan e-magazine.

Tabel 4.6 menunjukkan ketuntasan dari 30 peserta didik kelas uji coba lapangan utama dengan persentase ketuntasan sebesar $86,67 \%$ terdapat 4 peserta didik yang tidak tuntas karena memiliki nilai post-test dengan rentang
68-72 atau dibawah nilai KKM yang diberikan oleh guru yaitu 75, hal ini disebabkan karena peserta didik kurang teliti dalam mengerjakan dan memahami maksud dari soal terkhususnya pada nomor 1 dan 3 . Pada soal soal nomor 1 merupakan pertanyaan mengenai penjelasan perkembangan reaksi redoks beserta oksidator dan reduktor masingmasing konsep secara berurutan namun peserta didik hanya sekadar menuliskan perkembangan konsep tanpa adanya penjelasan. Kemudian pada soal nomor 3 peserta didik keliru dalam menentukan bilangan oksidasi unsur dalam senyawa dikarenakan kesalahan dalam perhitungan. Namun hal tersebut tidak mempengaruhi keefektifan e-magazine, media e-magazine yang dikembangkan dikatakan efektif jika peserta didik tuntas sebanyak $65 \%$ dari jumlah peserta didik dikelas tersebut setelah diuji menggunakan post-test (Nur et al., 2012) Tabel 10 menunjukkan bahwa hasil belajar yang dicapai peserta didik pada kelas uji coba lapangan utama yang menggunakan media $e$ magazine efektif.

Tahap setelah melakukan post-test yaitu pengisian angket respon guru dan peserta didik untuk mengetahui kepraktisan $e$ magazine yang dikembangkan pada uji coba lapangan utama, respon guru dan peserta didik memperoleh rentang skor 3-4 pada setiap aspek. Hasil analisis respon guru dan peserta didik menunjukkan respon terhadap $e$ magazine dengan rata-rata nilai sebesar $95,45 \%$ untuk hasil respon guru dan $85,5 \%$ untuk respon peserta didik berdasarkan hasil analisis tersebut dapat dikatakan semua aspek pada media e-magazine telah sesuai untuk digunakan sebagai media pembelajaran pada materi reaksi reduksi dan oksidasi sesuai dengan kriteria kepraktisan menurut Riduwan, maka nilai tersebut berada pada kriteria sangat praktis

Tabel 17. Rekapitulasi Hasil Angket Respon Guru dan Peserta Didik
Nilai Respon
Guru Peserta Didik 


\begin{tabular}{ccc}
\hline Uji Coba & $\mathbf{9 4 , 4 5 \%}$ & $\mathbf{8 5 , 5 \%}$ \\
Lapangan \\
Utama
\end{tabular}

Pada tahap ini dilakukan revisi berdasarkan hasil analisis respon guru dan peserta didik yang dilakukan pada uji coba lapangan utama yaitu berdasarkan hasil belajar peserta didik serta angket respon guru dan peserta didik. Rekapitulasi respon guru dan peserta didik pada uji coba lapangan utama dapat dilihat pada tabel 11 dan 12 .

Berdasarkan tabel 14 dapat diketahui bahwa respon guru dan peserta didik pada uji coba lapangan utama tidak mengarah pada revisi produk karena hanya memberikan saran atau komentar positif tentang media $e$ magazine yang dikembangkan. Oleh karena itu, media e-magazine yang dikembangkan tidak lagi direvisi dan dianggap sebagai produk akhir yang valid, efektif dan praktis untuk digunakan sebagai media pembelajaran.

\section{KESIMPULAN}

Penelitian pengembangan media $e$ magazine yang telah dilakukan, diperoleh kesimpulan yaitu telah berhasil dikembangkan e-magazine materi reaksi reduksi dan oksidasi untuk SMA/MA Kelas XI dengan menggunakan model ADDIE yang dapat membantu peserta didik dalam proses belajar dan menunjang keberhasilan belajar jarak jauh (belajar dari rumah). Media $e$ magazine yang dikembangkan pada penelitian ini telah valid, efektif, praktis serta layak digunakan sebagai media pembelajaran pada materi reaksi reduksi dan oksidasi dengan rincian : (a) hasil analisis kevalidan aspek materi dan aspek media menunjukkan nilai masing-masing sebesar 1,00 dengan kriteria valid. (b) Analisis keefektifan menunjukkan persentase ketuntasan pada uji coba lapangan awal sebesar $77,78 \%$ dan persentase ketuntasan pada uji coba lapangan utama pada kelas kontrol sebesar $66,67 \%$ sedangkan pada kelas eksperimen sebesar $86,67 \%$.

Analisis kepraktisan berdasarkan nilai respon guru pada uji coba lapangan awal sebesar $90,90 \%$ (kriteria sangat praktis) dan uji coba lapangan utama sebesar 95,45\% (kriteria sangat praktis), sedangkan nilai respon peserta didik untuk uji coba lapangan awal dan utama masing-masing sebesar 79,75\% (kriteria praktis) dan $85,5 \%$ (kriteria sangat praktis) Sehingga e-magazine yang dikembangkan dapat membantu proses belajar peserta didik dalam proses belajar materi reaksi reduksi dan oksidasi kelas X SMA/MA.

\section{DAFTAR PUSTAKA}

Amir, Z., \& Risnawati. (2016). Psikologi Pendidikan Pembelajaran Matematika. 193.

Annisa, A., \& Soeling, P. D. (2013). Pengaruh Employee Engagement Terhadap Kinerja Karyawan PT. Chandra Sakti Utama Leasing Jakarta. Universitas Indonesia, 1-19.

Febrilia, B. R. A., Nissa, I. C., Pujilestari, P., \& Setyawati, D. U. (2020). Analisis Keterlibatan Dan Respon Mahasiswa Dalam Pembelajaran Daring Menggunakan Google Classroom Di Masa Pandemi Covid-19. FIBONACCI: Jurnal Pendidikan Matematika Dan Matematika, 6(2), 175-184. https://doi.org/10.24853/FBC.6.2.175184

Hairida, \& Astuti, M. W. (2013). Self Efficacy dan Prestasi Belajar Siswa Dalam Pembelajaran IPA-Kimia. Jurnal Pendidikan Matematika Dan IPA, 3(1). https://doi.org/10.26418/JPMIPA.V3I1. 2207

Indriana, D. (2011). Ragam Alat Bantu Media Pengajaran. Diva Press.

Nisrina Nurul Faroh, D. S. (2018). Pengembangan Buku Cerita Bergambar Berbasis Montase dalam Pembelajaran IPS Kelas V. Joyful Learning Journal, 7(4), 34-42. https://doi.org/10.15294/jlj.v7i4.25089

Nur, R., Astuti, P., \& Trisnawati, R. (2012). Pengaruh Karakteristik Perusahaan Manufaktur Terhadap Pengungkapan Corporate Social Responsibility (Csr) Serta Dampaknya Terhadap Reaksi Investor ( Studi Pada Perusahaan Manufaktur Di Bursa Efek Indonesia Periode Tahun 2010-2013 ). www.idx.co.id, 
Oemar, Hamalik. (2009). Proses Belajar Mengajar (15th ed.). Bumi Aksara.

Pakpahan, A., Gani, A., \& Hasan, M. (2016). Pengembangan Majalah Kimia Pada Materi Hukum-hukum Dasar Kimia kelas X. Jurnal Ilmiah Mahasiswa Pendidikan Kimia, 1(4), 52-59. http://jim.unsyiah.ac.id/pendidikankimia/article/view/1364

Prasetyo, E. (2012). Data mining konsep dan aplikasi menggunakan MATLAB.

Puri, D. N. A., Epinur, E., \& Muhaimin, M. (2019). Pengembangan E-Magazine Materi Kesetimbangan Kimia di SMAN 1 Kota Jambi. Journal of The Indonesian Society of Integrated Chemistry, 11(1), 10-19.

https://doi.org/10.22437/jisic.v11i1.673 3

Riduwan. (2007). Skala Pengukuran Variabel-variabel Penelitian. Alfabeta.

Ristiyani, E., Evi, D., \& Bahriah, S. (2016). Analisis Kesulitan Belajar Kimia Siswa Di SMAN X KOTA. JPPI, 2(1), 18-29.

S. Eko Putro Widoyoko. (2009). Evaluasi Program Pembelajaran.

Setiaji, S.II., dan P. Yatiman. (2013). Pengembangan Majalah Kimia sebagai Sumber Belajar Mandiri pada Pembelajaran Kimia Peserta didik SMA/MA Kelas XII Materi Makromolekul. E Journal Universitas Negeri Yogyakarta, 3(88), 1-88. 